\title{
Zihin kuramı kazanımında bireysel farkların kaynağı: Dil, çalışma belleği, yönetici işlevler ve zihin kuramının boylamsal olarak incelenmesi*
}

\author{
Sources of individual differences in theory of mind: Longitudinal \\ investigation of theory of mind, working memory and theory of mind
}

\begin{abstract}
Makale Geçmişi
Geliş : 1 Haziran 2020

Düzeltme : 24 Ağustos 2020

Kabul : 27 Eylül 2020
\end{abstract}

Makale Türü

Araştırma Makalesi

Article History

Received : 1 June 2020

Revised : 24 August 2020

Accepted : 27 September 2020

\section{Article Type}

Research Article

\author{
Zehra Ertuğrul-Yaşar ${ }^{1}$, Sema Karakelle ${ }^{2}$
}

\begin{abstract}
Öz: Bu araştırmanın amacı 6 ay önceki bilișsel becerilerin ilerideki zihin kuramı (ZK) performansının ne kadarını açıkladığına ve 6 ayda ZK'da meydana gelen gelişimin kaynağının ne olduğuna odaklanarak ZK kazanımındaki bireysel farkları incelemektir. Çalışma 3-5 yaş arası toplam 70 çocuk üzerinde yürütülmüştür. Dil becerilerinin ölçümünde Türkçe İfade Edici ve Alıcı Dil Kelime Testi, çalışma belleğinin ölçümünde Bay Patates Görevi, yönetici işlevlerin ölçümünde Hazzın Ertelenmesi Görevi ile Boyut Değiştirerek Kart Eşleme Görevi kullanılmıştır. ZK gelişiminin incelenmesinde ise Zihin Kuramı Ölçeği kullanılmıştır. Katılımcılara 6 ay ara ile 2 kez ZK Ölçeği uygulanmıştır. İlk ZK oturumundan hemen önce ve son ZK oturumundan hemen sonra bilişsel beceriler ile ilgili ölçümler yapılmıştır. Önceki dil, çalışma belleği ve yönetici işlevler puanlarının birlikte, 6 ay sonraki ZK puanının \% 30’unu açıkladığı bulunmuştur. Ayrıca çocuklar arasındaki ZK gelişimine ilişkin bireysel farkların kaynağının, ifade edici kelime bilgisinde gösterdikleri gelişim ve zihinle ilgili mevcut kavramsal zeminleri olduğu bulunmuştur. Anahtar Kelimeler: Zihin Kuramı, Dil, Çalışma Belleği, Yönetici işlevler, Bireysel Farklar, Boylamsal
\end{abstract}

Abstract: The aim of this study was to investigate individual differences and variability in Theory of mind (TOM) development. This study was held on a total of 70 children aged between 3-5. For measurement of language ability, working memory and executive functions; TIFALDİ, Mr Peanut task, Delay of Gratification Task and Diemensional Card Sorting tasks were used, respectively. Additionally TOM scale was used for the investigation of TOM development. In terms of TOM development, participants were tested for 2 phases at 6 months intervals. Participants were tested before the first phase and after the last phase of TOM for language, working memory and executive functions. This study showed that previous language, working memory and executive functions together explain $30 \%$ of the six months later TOM score. Individual differences in TOM were explained in terms of the development in expressive vocabulary and the level of mind understanding of the children before experiment.

Keywords: Theory of Mind, Language, Working Memory, Executive Functions, Developmental Variability, Individual Differences

\footnotetext{
*Bu çalışma, ilk yazarın doktora tezinden üretilmiştir.

Başlica Yazar: Zehra Ertuğrul-Yaşar

${ }^{1}$ Erzurum Teknik Üniversitesi, Edebiyat Fakültesi, Psikoloji Bölümü, zehra.yasar@erzurum.edu.tr, ORCID: http://orcid.org/0000-0003-45433662

2 İstanbul Üniversitesi, Edebiyat Fakültesi, Psikoloji Bölümü, semakara@istanbul.edu.tr, ORCID: http://orcid.org/0000-0002-3899-6670
} 


\section{SUMMARY}

\section{Introduction}

Young children's understanding of how their understanding of mind develops is a significant and interesting topic in social-cognitive development. Since the late 1970s, when the theory of mind concept first came into use, age-related changes in theory of mind understanding have been described in detail in the literature. However, there are still queries regarding individual differences in ToM understanding. According to Wellman (2012), the reason for individual differences and developmental variability is that children with more developed abilities, such as attention or memory, which are crucial for TOM tasks, show more progress in the theory of mind understanding. The second probability is related to the "conceptual foundation" that is needed to reason about people's mind, behavior, and reality. Even when children do not succeed in TOM tasks, they may have more or less developed conceptual understanding, and this variation may result in different developmental paces.

The present study aims to investigate individual differences in the theory of mind understanding. It may be interesting to investigate whether changes in cognitive abilities, such as differences in the post-test-pre-test score of language, working memory, and executive functions, predict the change in the theory of mind understanding, and if so, how much of the variability in TOM understanding is explained by variability in other cognitive factors.

\section{Method}

This study was conducted on 70 children aged between 3-5. Demographic information was collected using a Personal Information Form for Children. The Ankara Developmental Screening Inventory developed by Savaşır, Sezgin and Erol (2005) was used as a prerequisite of this study to exclude any developmentally delayed children from this study. A battery of tests for the measurement of verbal ability, working memory, and executive functions were conducted both at the pre-test and post-test stages. The Turkish Expressive and Receptive Language Test developed by Berument and Güven (2010) was used to assess the vocabulary skills. The delay of gratification test, which was developed by Mischel, Schoda, and Rodriguez (1989) and The Dimensional Change Card Sort Task, which was developed by Frye, Zelazo, and Palfai (1995), was used in the measurement of executive functions. The Mr. Peanut task, which was developed by Case (1985), and adapted by de Ribaupierre and Bailleux (1994), was used to measure working memory. Additionally, a theory of mind scale (Wellman \& Liu, 2004) was used for the investigation of mental states, such as desires, beliefs, emotions, and knowledge. Concerning the theory of mind understanding, children were tested twice at 6month intervals. Children were tested individually in a quiet room at their preschool. There was no time lag between the pre-test and the first phase of the theory of mind and the post-test and the last phase of the theory of mind. Pre-test and post-test measurements were held in two sessions to prevent distractibility. The order of presentation of the tasks was kept constant. 


\section{Results}

Regarding the first problem, this study showed that the previous language, working memory and executive functions together accounted for $30 \%$ of the six months later TOM score.

To understand the source of the theory of mind development and the underlying causes of individual differences, we examined how much of the variability in the difference between the last and the first phase of theory of mind development is elucidated by age (concerning months), the theory of mind scores in the first phase and the difference between post-test and pre-test of language, executive functions, and working memory scores. Thus, linear regression analyses were performed. The results of the linear regression analyses showed that the development of language, working memory, executive functions in six months, age (in terms of months), and the first phase of theory of mind accounted for $32 \%$ of the variance in the theory of mind development. The findings obtained in this study showed that the post-test-pre-test difference in expressive language significantly contributed to the model $\left(t=2380, \mathrm{p}<.05, \mathrm{R}^{2}=.32\right)$ as did the first phase of theory of mind score $\left(t=3.247, \mathrm{p}<.05, \mathrm{R}^{2}=.32\right)$.

\section{Conclusion and Discussion}

All in all, the findings of this study suggest that developmental variability in TOM understanding is significantly explained by each child's conceptual/representational foundation and the progress s/he shows in expressive language. Children who had progressed more concerning expressive language in six months and who had progressed more regarding mental conceptual foundation at the beginning of this study showed more progress in the theory of mind understanding. However, other cognitive variables or age did not contribute significantly to the model.

The findings of this study are consistent with the argument that language is fundamental to theory-of-mind development. This result supports Wellman's (2012) views about explaining developmental variability based on a child's conceptual foundation of the mind. For Wellman, even when children do not succeed in TOM tasks, they may have conceptual understanding about the mind developed to a greater or lesser degree and so assimilate and accommodate information based on these different foundations. This, in turn, determines the developmental pace. 


\section{GİRİ̧̧}

Bilişsel gelişim açısından önemli bir kazanım olan zihin kuramı; arzulamak, bilmek, düşünmek, hissetmek gibi zihinsel durumları kendimize ve başkalarına atfedebilme becerilerimizi tanımlamak için kullanılan bir kavramdır (Sodian, 2005). Zihin hakkında bilgi ve anlayış kazanmak çocuklara, davranış ve zihinsel durumlara atıf yapma; davranışları ve sosyal dünyayı tahmin etme; yalan, ironi gibi kavramları anlamlandırma ve gerçeklikten farklı kanıları olabileceğini anlama gibi sosyal ve bilişsel dünya ile ilgili pek çok beceri için bir temel oluşturmaktadır (Flavell, Miller ve Miller, 2002).

Zihin kuramı kavramı ilk kez Premack ve Woodruft'ın (1978) şempanzelerle yaptığı araştırma ile alanyazına girmiş ve daha sonra çocuğun kendi ve başkalarının zihnini anlaması ile ilgili araştırmalar için kullanılan genel bir kavram olarak benimsenmiştir (Perner, 1991 sayfa 240). Zihin kuramı, 1978'de psikoloji alanyazınına girişinden günümüze kadar çok sayıda çalışmanın konusu olmuştur. Bu süreçte zihin kuramının tanım ve açıklamaları üzerinde tartışılmış, zihin kuramını açılamak için teoriler öne sürülmüş, zihin kuramının kazanılmasındaki gelişimsel değişimler anlaşılmaya çalışılmış, zihin kuramının etkilediği ve etkilendiği diğer bilişsel süreçler incelenmiş (Hasselhorn, Mahler, Grube, 2005), türler ve kültürler arasındaki zihin kuramı farklılıkları araştırılmıştır (Flavell, 1999). Araştırmalar ilerledikçe öncelikle okul öncesi gelişime odaklanan zihin kuramı çalışmaları niyetlilik, istek gibi diğer zihinsel durumları ve bebeklik ve orta çocukluk (Flavell, 1999) ve hatta yetişkinlik dönemlerini de ele almaya başlamıştır. Ayrıca normal gelişimin yanında otizm spektrum bozukluğu, işitme engeli, şizofreni gibi durumlarda zihin kuramı performansı incelenmeye ve zihin kuramının nöral bağlantılarını araştırmak için nörolojik görüntüleme tekniklerinden yararlanılmaya başlanmıştır.

\section{Zihin Kuramı ve Gelişimsel Çeşitlilik}

Alanyazında 3 ile 5 yaş arasındaki çocukların zihinsel dünyayı anlayarak yanlış kanı anlayışını kazanma açısından önemli bir gelişim yaşadıklarına dair bir fikir birliği vardır. Çocukların 3 yaşından önce yanlış kanı atfı yapamadıkları fakat 5 yaşından sonra bu beceriyi kazandıkları (Wellman, Cross, Watson, 2001) hemen hemen tüm zihin kuramı araştırmalarının kabul ettiği bir husustur. Fakat bu yaş aralığında tam olarak nasıl bir gelişim yaşandığı ve neyin geliştiği açıklanabilmiş değildir. Başka bir ifadeyle 1970'lerin sonunda zihin kuramı teriminin ortaya çıkmasından itibaren geçen süreçte zihin kuramı alanyazını değişim sürecinin doğası, örüntüsü ve olası bireysel farklılıklarını açıklama konusunda fazla ilerleme kaydetmiş gözükmemektedir (Amsterlaw ve Wellman, 2006). 
Bireysel farkları açıklamak üzere Hughes, Jaffee, Happé, Taylor, Caspi ve Moffitt (2006) tarafindan ikizler ile yapılan çalışmada zihin kuramındaki bireysel farkların çocukların genetiklerine nazaran paylaşılan çevreleri ile açıklandığı bulunmuştur. Bunun yanında kardeş sayısı (Ruffman, Naito, Perner ve Parkin ve Clements, 1998), sosyo-ekonomik statü (Cutting ve Dunn, 1999), annenin zihinsel durum bildiren kelime kullanımı (Ruffman, Slade ve Crowe, 2002), çocuğun sosyal kurum mu aile ortamında mı yetiştiği (Yağmurlu, Berument, Celimli; 2005) zihin kuramı gelişiminde önemli çevresel etkenlerdendir. Ayrıca Türk çocuklarında zihin kuramı gelişimi sıralaması, (Selcuk, Kimberly, Brink, Ekerim, Wellman, 2018) Çinli (Wellman, Fang, Liu, Zhu ve Liu; 2006; Wellman, Fang ve Peterson, 2011) ve İranlı (Shahaeian, Peterson, Slaughter ve Wellman, 2011) çocukların zihin kuramı gelişimi sıralaması ile uyumlu fakat Avusturalya, Amerika, Almanya ve Kanada'daki (Wellman, Fang ve Peterson, 2011) çocukların zihin kuramı sıralamasından farklıdır. Çocukların farklı zihinsel durumları temsilsel olarak farklı sıralama ile kazanması, çevresel etkilerin zihin kuramı üzerindeki etkisine bir diğer örnek olarak verilebilir.

Wellman'a (2012) göre zihin kuramındaki bireysel farklar ve gelişimsel çeşitliliğin nedeni zihin kuramından farklı olan ama zihin kuramının ölçülmesinde ve açıklanmasında gerekli olan bellek, dikkat, dil gibi becerilerin bazı çocuklarda daha çok gelişmiş olması olabilir (Wellman, 2012). Böylece örneğin daha güçlü belleği olan ya da daha gelişmiş dil becerisine sahip olan çocuklar, daha hızlı bir gelişme gösterebilirler. Bununla uyumlu olarak araştırmalar dil (Astington ve Jenkins, 1999; de Villiers ve de Villiers, 2000) yönetici işlevler (Carlson, Moses, Breton, 2002; Schneider, Lockl, Fernandez; 2005) bellek (Gordon ve Olson, 1998; Karakelle ve Ertuğrul, 2012; Slade ve Ruffman, 2005; Slade, Sodian, Taylor ve Keenan, 1998;) gibi bilişsel yapılar ile zihin kuramı arasında nedensel ilişkiler bulmuştur.

Özellikle dil ve zihin kuramı ilişkisi birçok araştırma tarafından tekrarlanan en güçlü ilişkilerin bulunduğu bilişsel yapıdır (Repacholi ve Slaughter, 2003). Bu çalışmalarda dil ile zihin kuramı arasındaki ilişki en az üç olasılık ile açıklanmaktadır: i) zihin kuramı, dili öngörüyor olabilir, ii) dil zihin kuramını öngörüyor olabilir, iii) dil ve zihin kuramı arasındaki ilişki üçüncü bir değişkene dayanıyor olabilir (Astington ve Jenkins, 1999). Dilin, zihin kuramını öngördüğünü öne süren görüşe göre dil ile zihin kuramı arasındaki ilişki dolaylı veya doğrudan olabilir. Dilin, zihin kuramını dolaylı olarak yordadığını öne süren görüşe göre, dil ile zihin kuramı arasındaki ilişki zihin kuramı görevlerinin sözel olması nedeniyle dil becerisine dayanmaktadır (Astington ve Jenkins, 1999). Doğrudan bir ilişki olduğunu savunan araştırmacılara göre ise dil, zihin kuramı anlayışının gelişmesi 
için kaynak sağlamaktadır. Örneğin dil zihinsel temsilleri geliştirmekte ve düzenlemekte ve böylece zihin kuramı anlayışının geliştirmesini desteklemektedir (de Villiers ve de Villiers, 2000). Zihin kuramının dili öngördügünü savunan görüşe göre ise zihin kuramı kazanımıyla birlikte temsil kazanımının gerçekleşmesi, dil becerisini geliştirmektedir. Diğer bir görüş, dil ve zihin kuramı arasında doğrudan bir ilişki olmadığı yönündedir. Başka bir deyişle dil ve zihin kuramı arasındaki ilişki, yönetici işlevler veya çalışma belleği gibi üçüncü bir aracı değişkene bağlanmaktadır. Bazı araştırmacılar ise çocuğu sosyal bağlam içerisinde ele alarak, çocuğun başkalarıyla iletişim halindeyken sosyal anlayışı diğerleriyle birlikte yapılandırdığını öne sürmektedir (Ilgaz ve Allen, 2020). Örneğin Tomasello (2018) dilin, zihinsel olanı ortak dikkat nesnesi niteliğine taşıdığını ve zihinsel durumlar ile ilgili farklı perspektiflerin olabileceğini ve gerçeklik ve öznellik arasında ayrım yapılabilmesini sağladığını öne sürmektedir. Türkiye'de yapılan araştırmalarda da dilin zihin kuramı üzerindeki etkisi, işitme engelli ya da otizmli çocuklar gibi atipik gelişme gösteren çocuklarda da kritik öneme sahiptir (Selçuk ve Yavuz, 2018).

Çalışma belleği ile zihin kuramı arasında ilişkide ise çalışma belleğinin zihin kuramı için gerekli olan farklı perspektifleri zihinde tutma becerisi vurgulanmaktadır (Carlson ve ark., 2002, Moses ve Tahiroğlu, 2010). Çoğu zihin kuramı görevi için gerekli olan zihinde tutma becerisi çalışma belleğini gerektirmektedir. Örneğin, yanlış kanı atfı testinde çocuğun başarılı olması için kendisinin ve başkasının perspektifini zihinde tutması gerekmektedir. Gordon ve Olson (1998) çalışma belleğinin temsilleri zihinde tuttuğunu, aynı nesneye ait farklı bir temsil girişi olduğunda bu temsilleri tekrar düzenlediğini böylece zihin kuramı gelişimine katkıda bulunduğunu belirtmektedir.

Yönetici işlevler ile zihin kuramı arasındaki ilişki ise Moses ve Tahiroğlu (2010) tarafından dört şekilde açlklanmıştır: i) iki beceri arasındaki ilişki, her iki becerinin ölçümünde kullanılan görevlerin kurallar/perspektifler arası geçiş gerektirmesinden kaynaklanıyor olabilir. Yönetici işlevler görevlerinde kurallar arasında geçiş yapamayan çocuklar, zihin kuramı için gerekli olan perspektifler arası geçişi de yapamıyor olabilir. ii) Zihin kuramı gelişiminde etkili olan (örneğin üstbilişsel) beceriler, bazı yönetici işlevler becerilerinin gelişimi için gerekli olabilir. iii) Zihin kuramı görevlerinin gerektirdiği yönetici işlevler becerilerinden dolayı çocuklar zihin kuramını kazanmış olmalarına rağmen görevi geçemiyor olabilir. iv) Zihin kuramı ile yönetici işlevler arasındaki ilişki, görev içerikleri nedeniyle değil daha kavramsal ve işlevsel olabilir. Örneğin zihin kuramını kazanabilmesi için yönetici işlevlerin ketleme alt boyutunu kazanmış olması gerekir. Ketleme becerisi kazanan çocuk, kendi perspektifini ketleyip farklı perspektifler arasında geçiş yapabilir ve zihin kuramını kazanabilir. Kısacası zihin kuramının açılanması ve ölçülmesi yönetici işlevler, dil, 
çalışma belleği gibi becerilere dayandığından bu beceriler açısından gelişmiş olan çocuklar yaşıtlarına nazaran daha hızlı bir gelişme gösterebilirler.

Wellman'a (2012) göre zihin kuramındaki bireysel farkların açıklanmasındaki bir başka olasılık gerçekliği ve insan davranışlarını anlamlandırmak için sahip olunan kavramsal zeminin başka bir deyişle mevcut zihinsel yapının temsil gücü ile ilgilidir (Wellman, 2012). Şöyle ki çocuklar zihin kuramı testlerini geçemedikleri zaman bile farklı derecede gelişmiş kavramsal zemine sahip olabilirler. Zihin kuramı görevini geçemeyen iki çocuktan biri, diğerine göre zihin ile ilgili daha soyut ve temsilsel bir kavramsal zemine sahip olabilir. Mevcut soyut ve kavramsal zihinsel yapisı nedeniyle bu çocuk diğer çocuktan daha hızlı bir gelişme gösterebilir. Wellman mevcut kavramsal zeminin, ilerideki zemini etkilemesini Piaget'nin özümleme ve uyumsama kavramlarıla örneklendirmektedir. Wellman’a göre mevcut bilişsel yapı üzerinden özümleme ve uyumsama gerçekleşmekte ve bu da bilişsel değişimi sağlamaktadır. Böylece araştırmaların ilk oturumu sırasında çocuğun zihin kuramı puanı başka bir deyişle önceki mevcut yapı ve kavramları ilerideki gelişimi için önemli olmaktadır.

Alanyazında zihin kuramı ile dilin/yönetici işlevlerin veya çalışma belleğinin ilişkisini inceleyen çok sayıda çalışma mevcuttur. Fakat bu araştırmalarda çoğunlukla ilk oturum bilişsel becerilerin, sonraki zihin kuramını nasıl yordadığı incelenmiş ve zihin kuramı sadece yanlış kanı atfı üzerinden değerlendirilmiştir. Mevcut çalışmada ise altı ay ara ile gerçekleştirilen iki oturumda hem zihin kuramı ölçümü, hem de dil, çalışma belleği, yönetici işlevler ölçümleri tekrarlanmıştır. Böylece çocukların altı ayda zihin kuramında, dil becerilerinde, yönetici işlevler ve çalışma belleğinde gösterdikleri gelişimi görmek; 2. zaman puanlarından, 1. zaman puanları çıkarılarak hesaplanan fark puanları aracılı̆̆ıla mümkün olmuştur. Ayrıca zihin kuramı arzu, kanı, bilgi, duygu gibi farklı zihinsel durumlar üzerinden değerlendirilerek zihin kuramının daha gelişimsel bir bakış açısı ile ele alınması sağlanmıştır. Sadece yanlış kanı atfi değil farklı zihinsel durumların gelişimi de incelendiğinden klasik zihin kuramı çalışmalarında "zihin kuramını geçemeyen” olarak nitelenen çocukların, zihinle ilgili yapı ve kavramlarına dair daha hassas bir ölçüm yapılabilmiştir. Örneğin klasik bir zihin kuramı çalışmasında yanlış kanı atfını geçemeyen çocukların zihin anlayışının aynı olduğu kabul edilmektedir. Hâlbuki bu çocuklardan bazıları henüz hiçbir zihinsel durumu zihinsel olarak temsil etmeye başlamamısken, bazıları arzu, kanı ve bilgiyi temsil etmeye başlamış olabilir. Bu çalışmada farklı zihinsel durumların temsili ile ilgili görevler kullanılması ve bu görevlerin belirli bir gelişimsel sıralama izlemesi nedeniyle çocuğun zihin kuramı puanından, zihinle ilgili hangi yapı ve kavramları kazandığını görmek mümkün olmuştur. 
Araştırmanın birinci sorusu kapsamında önceki çalışmalardan farklı olarak sadece yanlış kanı atfı değil arzu, kanı, bilgi, yanlış kanı, duygu gibi farklı zihinsel durumların değerlendirilmesiyle ölçülen zihin kuramı anlayışının; dil, çalışma belleği ve yönetici işlevler ile olan ilişkisi incelenmiştir. İkinci soruda ise önceki çalışmalardan farklı olarak çocukların 1. zaman dil, yönetici işlevler ve çalışma belleği puanları değil, ne kadar gelişim gösterdiklerine odaklanılmıştır. Örneğin, araştırma başladığında iki çocukta sadece arzuyu zihinsel olarak temsil edebiliyor olabilir. Altı ay sonra bu çocuklardan biri arzu ve kanıyı bir diğeri arzu, kanı, bilgi ve yanlış kanıyı zihinsel olarak temsil ediyor olabilir. Çocuklar arasındaki bu gelişimsel çeşitliliğge ve bireysel farklara neden olan nedir? Çocukların zihin kuramında altı ayda gösterdikleri farklı gelişimlerin kaynağı; dilde, çalışma belleğinde ve yönetici işlevlerde gösterdikleri farklı gelişim örüntüleri olabilir. Alıcı ve ifade edici kelime bilgisinde/yönetici işlevlerde/çalışma belleğinde daha çok gelişme gösteren çocuklar zihin kuramında da daha çok gelişim göstermiş olabilir. Çocuklardan biri altı aylık dönemde dilin alıcı ve ifade edici kelime bilgisinde önemli bir ilerleme kaydettiği için daha temsilsel düşünmeye başlamış bu da zihin kuramında daha çok gelişme göstermesine neden olmuş olabilir. Ya da altı aylık süre zarfında ketleme/bilişsel esneklik becerisinde önemli bir gelişme gösteren çocuk, çeldirici durumları daha iyi ketleyebildiği veya daha esnek düşünerek perspektifler arasında geçiş yapabildiği için gelişimin çeşitlenmesini sağlamış olabilir. Ya da Wellman'ın öne sürdüğü gibi çocuğun zihin kuramında ne kadar gelişim göstereceğini "mevcut zihin ile ilgili yap1 ve kavramları" başka bir deyişle ilk oturumdaki zihin kuramı puanı belirliyor olabilir. Örneğin; araştırma başladığında arzu, kanı ve bilgiyi temsil edebilenler, zihinle ilgili daha gelişmiş bir kavramsal zemine sahip oldukları için arzuyu temsil edenlere göre daha hızlı bir gelişme gösterebilirler. Kısacası araştırmanın ikinci sorusu kapsamında altı ayda zihin kuramında meydana gelen gelişimin kaynağı incelenecektir. $\mathrm{Bu}$ soruların cevabını bilmenin, 3-5 yaş arasında yaşanan zihin kuramı gelişimin doğasını ve örüntüsünü anlamak için önemli olduğu düşünülmektedir.

\section{Mevcut Çalışmanın Amacı ve Soruları}

Mevcut çalışmada ilk olarak 6 ay önceki dilin, çalışma belleğinin ve yönetici işlevlerin ilerideki zihin kuramı performansının ne kadarını açıkladığı incelenecektir. Böylece zihin kuramı ve diğer bilişsel değişkenler arasındaki boylamsal ilişkiler aydınlatılacaktır. İkinci olarak ise zihin kuramı gelişim kaynağının ve bireysel farkların nedeninin ne olduğunu anlamak için 6 ayda dil, yönetici işlevler, çalışma belleği açısından gösterilen gelişimin, çocuğun yaşının ve araştırma başladığında çocuğun zihin anlayışı düzeyinin; zihin kuramı gelişimi üzerindeki etkisi incelenmiştir

$\mathrm{Bu}$ araştırmanın soruları şu şekildedir: 
Soru 1) 1. zaman zihin kuramı puanları, 1. zaman yaş, dil ve yönetici işlev ve çalışma belleği; 2 . zaman zihin kuramı performansındaki değişkenliğin ne kadarını açıklamaktadır?

Soru 2) Dil, yönetici işlevler, çalışma belleği 1. ve 2. zaman ölçümleri arasındaki fark, yaş ve 1. zaman zihin kuramı; 2. zaman-1. zaman zihin kuramı farkındaki değişkenliğin ne kadarını açıklamaktadır?

\section{YÖNTEM}

\section{Kat1lımc1lar}

Bu çalışmanın ilk oturumunda 3-5 yaş (36-65 ay) arasındaki 85 çocuktan ölçüm alınmıştır. 6 ay sonra gerçekleştirilen ikinci ölçüm çocukların taşınması, okuldan ayrılması gibi nedenlerle 70 çocuk üzerinde yürütülmüştür. Bu nedenle analizler her iki ölçüme de 3 yaş (36-47 ay) 28, 4 yaş (48- 59 ay) 30 ve 5 yaş (60-65 ay) 12 olmak üzere toplam 70 (K:36 E:34) çocuk üzerinden gerçekleştirilmiştir. Katılımcılar basit seçkisiz örnekleme yöntemi ile belirlenmiştir.

Katılımcıların tamamı Erzurum'da bulunan üç okul öncesi eğitim kurumunda bulunmaktadır. Araştırmaya katılacak çocukların belirlenmesi için öğretmenlerinden, doğumda veya sonrasında hastanede yatmasını gerektiren önemli bir sağlık sorunu, sürekli bir hastalığı veya düzenli olarak ilaç kullanımı olmayan 36-65 aylık çocukları bildirmeleri istenmiştir. Bildirilen çocuklardan her iki ebeveyni de lise veya üzeri eğitime sahip olanlar için öğretmenleri tarafindan Ankara Gelişim Tarama Envanteri (AGTE) doldurulmuştur. AGTE'den aldıkları genel gelişim t-skoru normal yaş gelişimi sınırları içinde olan çocuklar araştırmanın katılımcısı olarak belirlenmiştir.

Annelerin \% 22'si ve babaların \%21'i lise, annelerin \% 74'ü ve babaların \% 77'si üniversite, annelerin \%4'ü babaların ise \%2'si lisansüstü eğitime sahiptirler. Annelerin \% 77'si ve babaların tümü çalışmaktadır. Ebeveynlerden sadece biri boşanmıştır ve çocukların \% $\% 3$ ’ü tek çocuktur.

\section{Veri Toplama Araçları}

Araştırmada dilin alıcı ve ifade edici kelime bilgisinin ölçümünde Türkçe İfade Edici ve Alıcı Dil Testi, Yönetici işlevlerin tepki ketleme alt boyutunun ölçümünde Hazzın Ertelenmesi Görevi, Yönetici işlevlerin bilişsel esneklik alt boyutunun ölçümü için Boyut Değiştirerek Kart Eşleme Görevi, Çalışma belleğinin ölçümünde Bay Patates Testi ve Zihin Kuramının ölçümünde Zihin Kuramı Ölçeği kullanılmıştır. Bazı sosyo demografik bilgiler kişisel bilgi formu ile ve çocukların genel gelişim düzeylerinin ölçülmesinde Ankara Gelişim ve Tarama Envanteri kullanılmıştır. 


\section{Sosyo-demografik Bilgilerin Ölçümü}

Kişisel Bilgi Formu. Araştırmacı tarafından geliştirilen Çocuklar için Kişisel Bilgi Formu çocuğun yaşı, cinsiyeti, anne/baba eğitim düzeyi gibi 11 sorudan oluşmaktadır. Formlar çocukların devam ettiği sınıfin öğretmeni tarafından doldurulmuştur.

\section{Genel Gelişim Düzeyinin Ölçümü}

Ankara Gelişim ve Tarama Envanteri (AGTE). Ankara Gelişim Tarama Envanteri Savaşır, Sezgin ve Erol (2005) tarafindan 0-6 yaş bebek ve çocukların gelişimini değerlendirmek amacıyla geliştirilmiştir.

Envanter, 154 maddeden oluşmakta ve her madde "Evet, Hayır veya Bilmiyorum" olarak cevaplanmaktadır. Envanter uygulanırken, çocuğun yaş diliminin hemen önceki yaş diliminden başlanmakta ve eğer bu bölümde çocuğun yapamadığı madde varsa bir önceki yaş dilimine geçilmektedir. Çocuğun üst üste 8 yanlış cevap verdiği yere kadar maddeler cevaplanmaya devam edilmektedir. Maddelere verilen cevaplar "Evet" ise 1, "Hayır" ise 0 puan verilmektedir. Başlama noktasından önceki tüm maddeler için 1 ve bitiş noktasından sonraki tüm maddeler için 0 puan verilmektedir. Böylece çocuğun genel gelişim düzeyinden alabileceği puan en fazla 154 en az 0 olmaktadır.

Envanterin güvenilirliği iç tutarlılık (toplam madde cronbach alfa değerleri 0-12 ay için .98, 13-44 ay için .97 ve 45-72 ay için .88) ve test tekrar test yöntemi (0-12 ay için $r=.99,13-48$ ay için $r=.98$ ve 49-72 ay için $r=.88$ ) ile incelenmiş ve güvenilirliğinin yüksek olduğu görülmüştür. Envanterin geçerliliğine baktı̆̆ımızda ise toplam puan ortalamalarının yaşla birlikte arttığını başka bir deyişle geçerli bir test olduğunu görmekteyiz.

$\mathrm{Bu}$ araştırmada AGTE çocuğun devam ettiği okul öncesi kurumdaki öğretmeni tarafindan doldurulmuştur. Çocukların gelişiminin yaşlarına uygun olup olmadığının belirlenmesi için sadece genel gelişim düzeyi puanları hesaplanmıștır. Daha sonra puanlama sonucu elde edilen ham puanlar t-skora çevrilerek yaş düzeyleri hesaplanmıştır. Savaşır ve ark. (2005) ham puanları 40-60 arası tpuana denk gelen çocukların gelişiminin yaşına uygun olduğunu belirtmesinden yola çıkarak sadece t puanları 40-60 arasında olan çocuklar bu araştırmaya dâhil edilmiştir.

\section{Dilin Alıcı ve Ífade Edici Kelime Bilgisi Öıçümü}


Türkçe İfade Edici ve Alıcı Dil Testi (Tifaldi). Berument ve Güven (2010) tarafindan geliştirilen Türkçe İfade edici ve Alıcı Dil Testi, 2-12 yaş çocukların dil gelişim düzeylerini ve dil gelişim aksaklıklarını belirlemek için kullanılmaktadır. Bu testin Alıcı Dil kelime bilgisi ve İfade Edici Dil kelime bilgisini ölçen iki alt testi vardır.

İfade Edici Alt Testi: İfade Edici Dil alt testinin, test-tekrar test (.97), iç tutarll1lk katsayıs1 (cronbcah's alfa $=.98)$ ve yarıya bölme güvenilirlik (Spearman-Brown = .99) değerleri ile güvenilir bir test olduğu gösterilmiştir. Ayrıca bu alt testin standart puanlarının WISC-R'ın genel, sözel ve performans puanları ile AGTE'nin standart, ham ve dil bilişsel gelişim alt testi puanları ile anlamlı şekilde ilişkili olduğu başka bir deyişle geçerli bir test olduğu bulunmuştur.

İfade Edici dil alt testinde çocuktan, gösterilen resmin ne olduğunu söylemesi istenir. Bu testten çocuğun alabileceği ham puan en yüksek 80 en düşük ise 0 'dır.

Alıcı Dil Alt Testi: Bu alt testin test-tekrar test güvenirliği (.97), iç tutarlılık katsayısı (Cronbach Alpha $=.99)$ ve yarıya bölme analizi (Spearman-Brown değeri .99) değerleri testin güvenilir olduğunu göstermektedir. Alıcı dil alt testi standart puanları WÇZÖ-R sözel, performans ve genel puanları ile ve AGTE t puanları, dil-biliş puanları ile anlamlı korelasyon göstermiştir.

Alıcı Alt dil testinde çocuktan araştırmacının söylediği kelimenin resmini 4 resim arasından bulması istenmektedir. Bu testten çocuğun alabileceği ham puan en fazla 104 en az 0'dır.

Bu araştırmada TİFALDİ'nin hem alıcı dil hem ifade edici alt testleri uygulanmıştır.

\section{Yönetici İslevlerin Ölçümü}

Hazzın Ertelenmesi (Delay of gratification). Hazzın Ertelenmesi görevi, Mischel, Schoda ve Rodriguez (1989) tarafından büyük fakat geç bir ödül kazanımı için anlık bir ödül kazanımını erteleyebilme becerisini ölçmek için kullanılmaktadır. Bu test yönetici işlevlerin tepki ketleme (response inhibition) alt boyutunu ölçmektedir. (Garon, Bryson, Smith 2008).

Çocuğun önüne bir tarafa bir jelibon diğer tarafa bir paket jelibon konarak hangisini istediği sorulmuştur. Çocukların hepsi paket jelibonu almak istemiştir. Araştırmacı dışarıda işi olduğunu, Eğer çocuk araştırmacıyı gelene kadar beklerse paket jelibonun onun olacağını, fakat beklemek istemezse araştırmacıyı çağırabileceği ve bu durumda bir tane jelibonun onun olacağı açıklanmıştır. Çocuğun kuralı anladığından emin olduktan sonra araştırmacı dışarı çıkmıştır. Araştırmacı çocuğun onu göremediği bir noktadan cep telefonu ile çocuğu canlı izlemiş aynı zamanda da çocuk kameraya 
alınmıştır. Çocuk jelibonu yerse veya araştırmacıyı çağırırsa içeri girilmiş ve bir tane jelibon çocuğa verilerek oyun sonlandırılmıştır. Bu durumda çocuk görevi geçememiş kabul edilerek 0 puan verilmiştir. Çocuğun jelibonu yemediği ve araştırmacıyı çağırmadığı durumlarda ise 5 dakika sonra araştırmacı odaya geri dönmüş ve çocuğa 1 puan verilmiştir.

Boyut Değiştirerek Kart Eşleme Görevi (BDKE). Boyut değiştirerek kart eşleme görevi (BDKE), yönetici işlevlerin bilişsel esneklik alt boyutunun ölçümü için Frye, Zelazo ve Palfai (1995) tarafından geliştirilmiştir. Frye, Zelazo ve Pafaiden kullanım için izin alınmış ve görevin materyalleri kendilerinden temin edilerek belirtilen ölçekte basılmıştır. Görev ilk kez birinci araştırmacının yüksek lisans tezinde kullanılmıs ve anlaşılma ve uygulanma açısından bir sorunla karşılaşılmamıştır.

İki eşleme tepsisi yan yana gelecek şekilde masaya yerleştirilmiş ve her birinin başına hedef kartları (mavi tavşan ve kırmızı gemi) yerleştirilmiştir. Birinci aşamada çocuktan eşleme kartlarını renklerine göre eşleştirmesi istenmiş ve her karttan önce kural hatırlatılmış ve toplamda 6 kart eşleştirilmiştir. Tüm kartları uygun tepsiye yerleştiren çocuklar ikinci aşamaya geçmiştir. İkinci aşamada çocuktan kartları şekline göre eşleştirmesi istenmiştir ve her karttan önce kural hatırlatılmış ve toplamda 6 kart eşleştirilmiştir. 6 karttan en az 5’ini doğru tepsiye yerleştirenler üçüncü aşamaya geçmiştir. Üçüncü aşamada çerçeveli kartlarda oyuna eklenmiş ve çocuktan çerçeveli kart gördügünde renk oyununa göre çerçevesiz kart gördüğünde şekil oyununa göre oynaması istenmiştir. Bu aşamada 7 çerçeveli ve 5 çerçevesiz kartın eşleştirilmesi istenmiş ve 12 karttan en az 9’unu doğru tepsiye yerleştiren çocukların aşamayı geçtiği kabul edilmiştir. Geçilen her aşama için çocuğa 1 puan verilerek görevden alınabilecek en yüksek puan 3 en düşük puan 0 olarak hesaplanmıştır.

\section{Çalışma Belleğinin Ölçümü}

Bay Patates Testi (Mr. Peanut Testi). Case (1985) tarafindan geliştirilen bu test de Ribaupierre ve Bailleux (1994) tarafindan uyarlanmıştır. Araştırmacı tarafından yönerge Türkçe'ye çevirtilmiş ve test materyalleri hazırlanmıştır. 3, 4 ve 5 yaş çocukları ile yapılan pilot çalışma ile görevin anlaşılırlığ1 incelenmiştir.

Uygulamada çocuğa vücudunun farklı yerlerinde 1 ila 8 arası çıkartma yapıştırılan toplam 24 'Bay Patates’ figürü sırasıyla 5 saniye gösterilmiştir. Her bir figür gösterildikten sonra kapatılmış ve çocuğun noktaların yerlerini göstermesi için çıkartması/noktasız boş 'Bay Patates' resmi gösterilmiştir. Çocuk aynı seviyedeki 3 resmi de yanlış cevapladığında görev sona ermiştir. Böylece bu görevden alınabilecek en yüksek puan 8 en düşük puan 0'dır. 


\section{Zihin Kuramı Becerilerinin Ölçümü}

Zihin Kuramı Ölçeği. Zihin kuramının ölçümü için Wellman ve Liu (2004) tarafından geliştirilen ve doktora tezi kapsamında Kahraman (2012) tarafından Türkçe'ye uyarlama çalışması yapılan Zihin Kuramı Ölçeği kullanılmıştır.

Wellman ve Liu'nun (2004) tavsiye ettiği sıralama olan Farklı- İstek, Farklı Kanı, Bilgi-Erişim, İçerik Yanlış Kanı, Belirgin Yanlış Kanı, Gerçek-Görünen Duygu sıralamasıyla uygulama gerçekleştirilmiştir. Çocuğun görevleri daha iyi anlaması için gerçek nesneler (gerçek havuç ve kurabiye gibi), oyuncak insan ve hayvan figürleri kullanılmıştır.

Zihin kuramı ölçeğinin alt görevlerinden geçebilmek için çocuğun hafiza kontrol ve hedef sorularının her ikisini de doğru yanıtlaması veya hedef sorusuna verdiği cevabın kendi istek/kanı/bilgisine verdiği cevabın tersi şeklinde yanıtlaması gerekmektedir. Çocuk, alt görevi geçtiği durumda 1 puan, geçemediği durumda ise 0 puan almaktadır. Böylece her bir alt testten alınabilecek en yüksek puan 1 en düşük puan 0 ve ölçekten alınabilecek toplam puan en yüksek 6 en düşük 0 olmaktadır.

\section{İşlem}

İstanbul Üniversitesi Sosyal ve Beşeri Bilimler Etik Kuruluna başvurulmuş ve onay alınmıştır (Sayı: 2014/16, Tarih: 10.11.2014). Okul yönetimlerine araştırmanın amacı, araştırmada uygulanacak ölçekler ve amaçları açıklanmış ve uygulama için izin alınmıştır. İzin alınan okullarda araştırmaya katılım için uygun şartları sağlayan çocukların velilerine bilgilendirilmiş onam formu gönderilmiştir. Velisi tarafından araştırmaya katılması onaylanan ve işbirliği yapmayı isteyen çocuklar, araştırmanın katılımcısı olarak belirlenmiştir. Erzurum'da bulunan üç anaokulunda araştırma gerçekleştirilmiştir.

Veri toplama süreci birinci araştırmacı ve bir psikolojik danışmanlık ve rehberlik lisans öğrencisi tarafından gerçekleştirilmiştir. Uygulamalar çocuğun bulunduğu anaokulunda araştırmacıya tahsis edilen ve fiziksel olarak araştırmaya uygun olan (çocuğa uygun sandalye ve masa olan, sessiz vb.) bir odada birebir olarak gerçekleştirilmiştir.

Çocuğun dikkatinin dağılmaması amacıyla 1. oturumda dil testleri, 2. oturumda çalışma belleği ve yönetici işlevler testleri, 3. oturumda zihin kuramı görevi uygulanmıştır. Bir çocuktan toplanan veriler aynı hafta içerisinde tamamlanmıştır. 6 ay sonra işlem aynı sıra ve düzende 3 oturumda tekrarlanmıştır. 
Dil testleri yaklaşı olarak 20-35 dakika, BDKE görevi 10-15 dakika, Pay Patates Görevi 5-10 dakika, Hazzın Ertelenmesi görevi yaklaşı 5 dakika ve Zihin kuramı oturumları ortalama 15- 20 dakika sürmüştür.

\section{BULGULAR}

$\mathrm{Bu}$ çalışmada verilerin çarpıklık (Skewness)-basıklık (Kurtosis) değerleri incelenerek normal dağılıma sahip olup olmadıkları test edilmiştir. Bulgular Dilin Alıcı ve İfade Edici kelime bilgisinin, çalışma belleğinin, yönetici işlevlerin ve zihin kuramının ölçümüne dair verilerin çarpıklık ve basıklık değerlerinin +1.5 ile -1.5 aralığında olduğunu göstermiştir. Değerler, Tabachnick ve Fidell’in (2013) çarpıklık ve basıklık için önerdiği referans değerleri arasında olduğu için verilerin normal dağılıma sahip olduğu kabul edilmiştir.

Araştırmanın problemlerine geçmeden önce tüm gruba ilişkin betimsel analizlere yer verilmiştir. Tablo 1'de katılımcıların yaş gruplarına göre 1. ve 2. zaman zihin kuramı, alıcı ve ifade edici kelime bilgisi, çalışma belleği, yönetici işlevler görevleri puan ortalama ve standart sapma değerleri verilmiştir.

Tablo 1. Katılımcıların 1. zaman ve 2. zamanda bilişsel değişkenlerden aldıkları puanların ortalama ve standart sapma değerleri

\begin{tabular}{|c|c|c|c|c|c|c|}
\hline & \multicolumn{2}{|c|}{3 yaş } & \multicolumn{2}{|c|}{4 yaş } & \multicolumn{2}{|c|}{5 yaş } \\
\hline & Ort. & SS & Ort. & SS & Ort. & SS \\
\hline 1. Zaman BDKE & 1,25 & 0,75 & 1,50 & 0,57 & 1,75 & 0,45 \\
\hline 1. Zaman Hazzın Ertelenmesi & 0,64 & 0,49 & 0,87 & 0,35 & 0,92 & 0,29 \\
\hline 1. Zaman Alıc1 Dil Kelime Bilgisi & 36,50 & 16,35 & 57,73 & 15,43 & 67,33 & 10,26 \\
\hline 1. Zaman İfade Edici Kelime Bilgisi & 32,21 & 10,71 & 44,90 & 11,82 & 53,33 & 8,50 \\
\hline 1. Zaman Bay Patates Görevi & 1,14 & 0,66 & 1,48 & 0,54 & 1,66 & 0,70 \\
\hline 2. Zaman BDKE & 1,61 & 0,63 & 1,70 & 0,53 & 2,08 & 0,51 \\
\hline 2. Zaman Hazzın Ertelenmesi & 0,61 & 0,50 & 0,83 & 0,38 & 0,83 & 0,39 \\
\hline 2. Zaman İfade Edici Dil Kelime Bilgisi & 50,07 & 16,46 & 67,50 & 13,78 & 79,50 & 9,20 \\
\hline 2. Zaman Alıcı Dil Kelime Bilgisi & 41,18 & 7,96 & 51,07 & 10,02 & 58,50 & 6,70 \\
\hline 2. Zaman Bay Patates Görevi & 1,57 & 0,57 & 1,99 & 0,70 & 2,05 & 0,62 \\
\hline
\end{tabular}

Tablo 1'e göre tüm yaş grupları, hazzın ertelenmesi hariç diğer bilişsel değişkenler açısından 2. zaman ile 1. zaman arasında bir puan artışı göstermiştir.

Zihin kuramı ile diğer bilişsel değişkenler arasında yaştan kaynaklı olmayan ilişkilerin aydınlatılması için yaş kontrol edilerek kısmi korelasyon analizi yapılmıştır. Tablo 2'de yaş ayı kontrol edilerek 1. 
zaman alıcı ve ifade edici kelime bilgisi, çalışma belleği, yönetici işlevler görevleri puanları ile 2. zaman zihin kuramı puanı arasında yapılan kısmi korelasyon analizi sonuçları verilmiştir.

Tablo 2. Yaş kontrol edildiğinde 1. zaman bilişsel değişkenlerden alınan puanlar ile 2. zaman zihin kuramı ölçeğinden alınan puanlar arasındaki kısmi korelasyon katsayıları.

\begin{tabular}{ll}
\hline & 2. Zaman ZK \\
\hline 1. Zaman Alıcı Dil Kelime Bilgisi &, $46^{* *}$ \\
1. Zaman İfade Ed. Kelime Bilgisi &, $45^{* *}$ \\
1. Zaman Çal. Bel. &, $25^{*}$ \\
1. Zaman Haz. Ert. &, $30^{* *}$ \\
1. Zaman Bdke &, $27^{*}$ \\
\hline
\end{tabular}

Tablo 2'ye göre göre yaş kontrol edildiğinde 2. zaman toplam zihin kuramı puanı; 1. zaman alıcı ve ifade edici kelime bilgisi puanlanı ile orta derecede, çalışma belleği ve yönetici işlevler puanları ile zayıf derecede ilişkili bulunmuştur.

\section{Birinci Probleme İlişkin Bulgular}

Çocuğun 6 ay önceki bilişsel değisskenlerde gösterdiği performansın, ilerideki zihin kuramı anlayışının ne kadarını açıkladığı incelenmiştir. Araştırmanın birinci problemi 1. zaman yaş, dil, yönetici işlevler ve çalışma belleğinin; 2. zaman zihin kuramı performansındaki değişkenliğin ne kadarını açıkladığı olarak ifade edilmişti. Bu amaçla 1. zaman alıcı ve ifade edici kelime bilgisi, çalışma belleği, hazzın ertelenmesi ve BDKE puanları ve yaş ile 1. zaman zihin kuramı puanının; ikinci zamandaki zihin kuramı puanına ait değişkenliğin ne kadarını açıladığı incelenmiştir. Bu amaçla 3 aşamalı hiyerarşik regresyon analizi uygulanmıştır.

Doğrusal regresyon varsayımlarını sağlayabilmek için önce Durbin Watson değerine bakılmış bu değer 2,39 olduğu için oto korelasyon olmadığı görülmüştür. Değişkenler arasındaki ilişkinin doğrusal olup olmadığ1 saçılma diyagramı ile incelenmiş ve ilişkinin doğrusal olduğu görülmüştür. Hata terimlerinin normal dağıldığı bulunmuştur. Fakat varyans genişlik faktörü (VIF) değerlerinin ,10'dan büyük ve tolerans değerlerinin ,20'den küçük olduğu görülmüsstür. VIF ve tolerans değerleri göz önüne alındığında bu değişkenler arasında çoklu bağlantı (multicollinearity) olduğunu söylemek mümkündür. Başka bir deyişle bu değişkenler birbirleriyle güçlü ilişki içerisinde olduğu için model anlamlı fakat değişkenlerin modele katkısı anlamsız olmuştur. Bu nedenle tüm değişkenler ile arasında yüksek korelasyon bulunan yaş değişkeni ve ifade edici kelime bilgisi ile arasında yüksek 
korelasyon bulunan alıcı dil değişkeni modelden çıkartılmıştır ${ }^{1}$. Böylece ifade edici kelime bilgisi, çalışma belleği, yönetici işlevler ve 1. zamandaki zihin kuramı puanları ile 2. zaman zihin kuramı puanı arasında 3 aşamalı hiyerarşik regresyon analizi uygulanmıştır. 1. zaman zihin kuramı puanı 1. aşamada, ifade edici kelime bilgisi 2. aşamada ve çalışma belleği ve yönetici işlevler 3. aşamada analize dâhil edilmiştir. Analiz sonucu yapılan çoklu bağlantı analizlerinde çoklu bağlantı sorununun yaş ve alıcı dil değişkenlerinin kaldırılması ile ortadan kalktığı görülmüştür. Regresyon analizi sonuçları Tablo 3’te gösterilmektedir.

Tablo 3. Hiyerarşik regresyon analizi sonuçları

\begin{tabular}{llllc}
\hline & B & Standart Hata & B & $\begin{array}{c}\text { R } \\
\text { Değişimi }\end{array}$ \\
\hline 1. Model & & & &, 20 \\
1. Zaman Zihin Kuramı & 4,97 & 0,117 & $0,453^{*}$ &, 9 \\
$\begin{array}{l}\text { 2. Model } \\
\text { 1. Zaman Zihin Kuramı }\end{array}$ & 0,348 & 0,122 & & \\
Ifade Edici Dil & 0,35 & 0,012 & $0,317^{*}$ &, 1 \\
3. Model & & & $0,328^{*}$ & \\
1. Zaman Zihin Kuramı &, 318 & 0,127 & $0,290^{*}$ & \\
İfade Edici Dil &, 030 & 0,013 & $0,277^{*}$ & \\
Çalı̧ma Belleği &, 028 & 0,260 & 0,013 & \\
Yönetici İșlevler &, 200 & 0,213 & 0,118 & \\
\hline
\end{tabular}

1. modelde F testi sonuçlarının anlamlı olması 2. zaman zihin kuramının 1. zaman zihin kuramı puanı ile açıklanabileceğini göstermektedir, $R^{2}=.20, F(1,71)=18,08, p<.05$. 2. aşamada modele ifade edici kelime bilgisi eklendiğinde açılklanan varyans değerindeki değişim anlamlı olmuştur, $R^{2}$ $=.29, F(2,71)=14,38, p<.05$. 3. aşamada modele çalışma belleği ve yönetici işlevler görevleri dâhil edilmiştir. 3. modele göre ifade edici kelime bilgisi ve 1. zaman zihin kuramı, 2. zaman zihin kuramının yordanmasına anlamlı katkıda bulunmuştur $\left.R^{2}=30, F(4,71)=7,36, p<.05\right)$.

\section{İkinci Probleme İlişkin Bulgular}

Zihin kuramı gelişim kaynağının ve bireysel farkların nedeninin ne olduğunu anlamak için 6 ayda dil, yönetici işlevler, çalışma belleği açısından gösterilen gelişimin, çocuğun yaşının ve araştırma başladığında çocuğun zihin anlayışı düzeyinin; zihin kuramı gelişimi üzerindeki etkisi incelenmiştir.

\footnotetext{
${ }^{1}$ Alıcı dil yerine ifade edici dil modelden çıkarılıp 3 aşamalı hiyerarşik regresyon analizi yapıldığında benzer şekilde 3 . modelin zihin kuramının \%31'ini açıkladığı ve 1. zamandaki zihin kuramı ile alıc1 dilin modele anlamlı katkıda bulunduğu görülmektedir.
} 
Araştırmanın ikinci problemi dil, yönetici işlevler, çalışma belleği 1. ve 2. zaman ölçümleri arasındaki farkın, yaşın ve 1. zaman zihin kuramının; 1. zaman ve 2. zaman zihin kuramı farkındaki değişkenliğin ne kadarını açıkladığı olarak ifade edilmişti. Bu amaçla 2. zaman ve 1. zaman arasındaki alıcı ve ifade edici kelime bilgisi, çalısma belleği, yönetici işlevler puan farkı ve çocuğun yaşı ile 1. zaman zihin kuramı puanının; 2. zaman ve 1. zaman zihin kuramı farkının ne kadarını açıkladığı incelenmiştir.

Doğrusal regresyon analizi sonuçları Tablo 4’te gösterilmektedir.

Tablo 4. Doğrusal regresyon analizi sonuçları

\begin{tabular}{llllll}
\hline & B & $\begin{array}{l}\text { Standart } \\
\text { Hata }\end{array}$ & Beta & T & sig. \\
\hline Alııı D. puan fark1 &, 007 &, 020 &, 046 &, 341 &, 341 \\
İfade Ed. puan fark1 &, 076 &, 032 &, 324 & 2,380 &, $022^{*}$ \\
Çal.Bel.puan fark1 &, 405 &, 291 &, 183 & 1,394 &, 171 \\
Yön. İşıl. Puan fark1 &, 018 &, 251 &, 009 &, 072 &, 943 \\
Yaş &, 031 &, 026 &, 189 & 1,197 &, 238 \\
1. Zaman ZK &, 605 &, 186 &, 494 & 3,247 &, $002^{*}$ \\
\hline
\end{tabular}

Doğrusal regresyon analizi modelin, zihin kuramında 6 ayda meydana gelen gelişimin \% 32'sini açıkladığ1 görülmüştür. 2. zaman-1. zaman ifade edici kelime bilgisi puan farkının $(t=2380, p<.05$, $\left.R^{2}=.32\right)$ ve 1. zamandaki zihin kuramı puanının $\left(t=3,247, p<.05, R^{2}=.32\right)$, modele anlamlı katk1 sağladığı bulunmuştur. Kısacası zihin kuramında 6 ayda meydana gelen gelişim, ifade edici kelime bilgisinde 6 ayda meydana gelen gelişim ve çocuğun araştırma başladığı zamanki zihin anlayışının düzeyi ile anlamlı olarak yordanmaktadır. İfade edici dilde daha çok gelişme gösteren çocuklar ile zihin ile ilgili daha gelişmiş bir kavramsal zemine sahip olan çocuklar; zihin kuramında daha çok gelişme göstermişlerdir. Böylece zihin kuramı gelişiminin kaynağının ve bireysel farkların nedeninin, çocuğun ifade edici kelime bilgisinde yaşadığı gelişim ve zihin ile ilgili mevcut kavramsal zemini olduğu görülmüştür.

\section{SONUÇ ve TARTIŞMA}

Bu araştırmada önceki zihin kuramı, dil, çalışma belleği, yönetici işlevler becerilerinin, ilerideki zihin kuramı performansının ne kadarını açıladığına ve 6 ayda ZK'da meydana gelen gelişimin kaynağına odaklanarak ZK kazanımındaki bireysel farklar incelenmiştir. Çalışmanın bulguları çerçevesinde ilk problemde çocuğun önceki dil, yönetici işlevler ve çalışma belleği puanlarının; ilerideki zihin kuramı 
performansındaki değişkenliğin ne kadarını açıkladığı incelenmiş ve önceki ifade edici kelime bilgisi ile 1. zamandaki zihin kuramının, ileriki zihin kuramının yordanmasına anlamlı katkıda bulunduğu bulunmuştur. İkinci problemde altı ayda dil, yönetici işlevler, çalışma belleğinde meydana gelen gelişimin, yaşın ve 1. zamandaki zihin kuramının; altı ayda zihin kuramında meydana gelen gelişimin ne kadarını açıkladığı incelenmiştir. Analizler sonucunda ifade edici kelime bilgisinde meydana gelen gelişim ile çocuğun araştırma başladığı zamanki zihin kuramı puanının, zihin kuramında 6 ayda meydana gelen gelişimi anlamlı olarak yordadığı görülmüştür. Bu bulgular, ifade edici kelime bilgisinde daha çok gelişme gösteren çocuklar ile zihin ile ilgili daha gelişmiş bir kavramsal zemine sahip olan çocukların; zihin kuramında daha çok gelişme gösterdiklerini ortaya koymuştur.

$\mathrm{Bu}$ araştırmanın 1. problemi kapsamında ilerideki zihin kuramının \%30’unun; önceki dil, çalışma belleği, yönetici işlevler ve zihin kuramı ile açıklanabildiği bulunmuştur. Dahası çocukların mevcut kavramsal zeminlerinin ve ifade edici kelime bilgisindeki gelissimlerinin, ileride zihin kuramı açısından ne derece bir gelişim göstereceklerini belirlediği ortaya çıkmıştır. Oberauer’in (2005) belirttiği gibi zihin kuramın, bilişsel becerileri etkileyen ve/veya onlardan etkilenen bir beceri olarak kavramlaştırılması eksiktir ve bunun yanı sıra zihin kuramı sadece dil, çalışma belleği gibi değişkenlerle de açıklanamamaktadır. Benzer şekilde bu araştırmada da önceki dil, çalışma belleği ve yönetici işlevler ilerideki zihin kuramı performansıyla ilişkili bulunmuştur fakat bu bilişsel değişkenler birlikte zihin kuramının ancak bir kısmını açıklayabilmiştir. Bu nedenle bu araştırmanın bulguları çerçevesinde zihin kuramının sırf dil, çalışma belleği, yönetici işlevler becerilerine indirgenemeyeceği açıktır. Bu noktada Perner (1991), Flavell (1988) gibi araştırmacılar zihin kuramını, diğer bilişsel becerilerdeki gelişime değil, temsil becerisine ve temsilsel bir zihin anlayışına dayandırmaktadır.

Mevcut çalışmayla uyumlu olarak, dil ile zihin kuramı arasındaki ilişki birçok araştırma tarafindan ortaya konulmuştur (Astington ve Jenkins, 1999; de Villiers ve de Villiers, 2000; Repacholi ve Slaughter,2003). Bu çalışmalara göre dil, zihin kuramını belirliyor olabilir; zihin kuramı, dili belirliyor olabilir ya da dil- zihin kuramı arasındaki ilişki, üçüncü bir aracı değişkene dayanıyor olabilir. Mevcut araştırmanın bulguları ise dilin, zihin kuramını öngördüğünü belirten açıklamayla uyuşmaktadır. Zihin kuramı görevlerinin gerektirdiği dil becerisi nedeniyle dil, ileriki zihin kuramı performansını dolaylı olarak da belirlemiş olabilir. Buna göre bu araştırmada kullanılan zihin kuramı görevlerinin anlaşılması ve doğru cevaplanması çocuğun alıcı ve ifade edici kelime bilgisine dayanıor gözükmektedir. Mevcut araştırmada dilin alıcı ve ifade edici kelime bilgisinin, zihin kuramı üzerinde doğrudan bir etkisi olduğunu da söyleyebiliriz. Dilin alıcı ve ifade edici kelime bilgisi, zihin anlayışının gelişmesine kaynaklık sağlayarak ve zihnin temsilsel kapasitesini destekleyerek araştırmadaki çocukların ileriki zihin kuramını öngörmüş olabilir. 
$\mathrm{Bu}$ araştırmadaki çalışma belleği ile zihin kuramı arasındaki ilişki, çalışma belleğinin malumatları zihinde tutma ve işlemleme kapasitesi üzerinden açıklanabilir (Carlson ve ark., 2002). Çalışma belleği temsilleri zihinde tutma ve onları işlemleme kapasitesi sayesinde ilerideki zihin kuramı ile ilişskili bulunmuş olabilir. Ayrıca çalışma belleği- zihin kuramı ilişkisi, zihin kuramı görevlerinin içeriğinden de kaynaklanıyor olabilir. Bu çalışmada kullanılan zihin kuramı görevlerinde çocuğun görevdeki karakterin arzusunu/kanısını vb. hatırlaması ve hafıza-kontrol sorularına doğru cevap vermesi gerektiğinden, görevlerin çalışma belleği gerektirdiği açıktır.

Bu çalışmada geniş bir kavram olan yönetici işlevler, ketleme ve kural değişimi (bilişsel esneklik) alt boyutları ile değerlendirilmiştir. Zihin kuramı, yaş kontrol edildiğinde yönetici işlevler ve çalışma belleği ile ilişkili bulunmuştur fakat özellikle çalışma belleği- zihin kuramı ilişkinin gücü zayıftır. Bu çalışmadakinden farklı görevlerle ketleme, kural değişimi ve çalışma belleğini ölçen Hughes (1998) çalışmasında çalışma belleği ve ketlemenin zihin kuramı ile ilişkili olduğunu fakat yaş kontrol edildiğinde çalışma belleği ile zihin kuramı arasında anlamlı ilişki bulunamadığını belirtmiştir. Benzer şekilde Carlson ve ark. (2002) ketleme görevi ile zihin kuramı arasındaki ilişkinin yaş kontrol edildiğinde devam ettiğini fakat çalışma belleği- zihin kuramı arasındaki ilişkinin devam etmediğini belirtmektedir. Mevcut çalışmada ise yaş kontrol edildiğinde zayıf kuvvette de olsa zihin kuramının çalışma belleği ve ketleme görevi ile ilişkisi devam etmiştir. Bu durum mevcut çalışmada kullanılan zihin kuramı görevlerinin, klasik yanlış kanı görevlerinden daha çok çalışma belleğinin zihinde tutma becerisine dayanıyor olmasından kaynaklanıyor olabilir.

Zihin kuramı ile diğer bilişsel değişkenler arasındaki ilişki açısından çocukların zihin kuramı kazanımına ilişkin gösterdikleri farklı gelişimlerin, dilin alıcı ve ifade edici kelime bilgisi, yönetici işlevler ve çalışma belleği gelişimi ile açıklanıp açıklanmadı̆̆ını görmek de önemli gözükmektedir. Bu çalışmanın 2. problemi kapsamında zihin kuramındaki 6 aylık gelişimin açıklanması için kurulan modelde çocukların zihinle ilgili mevcut kavramsal zeminlerinin ve ifade edici kelime bilgisinde gösterdikleri gelişimin, ileride zihin kuramı açısından ne derece bir gelişim göstereceklerini belirlediği görülmüştür. Buna göre zihinle ilgili daha gelişmiş anlayışı olan ve ifade edici kelime bilgisinde daha çok gelişim gösteren çocuklar, zihin kuramında daha çok gelişme göstermişlerdir. $\mathrm{Bu}$ bulgu çocuklar arasındaki zihin kuramı gelişimine ilişkin bireysel farkların ve gelişimsel çeşitliliğin kaynağının, ifade edici kelime bilgisinde gösterdikleri gelişim ve zihinle ilgili mevcut kavramsal zeminleri olduğuna işaret etmektedir.

Bu noktada Wellman (2012) zihin kuramının kazanılmasındaki bireysel farklar ve gelişimsel çeşitliliği iki olasıllğa bağlamaktadır. İlk olarak dil, çalışma belleği gibi bilişsel değişkenlerin farklı gelişmişlik düzeyleri, çocukların zihin kuramı gelişim hızını belirliyor olabilir. Wellman'ın burada 
bahsettiği bilişsel değişkenlerin zihin kuramının özünde bir farklılık yaratması değil bu değişkenlerin zihin kuramının açıklanmasında ve ölçülmesinde etkili olmalarıdır. Bu araştırmada ifade edici kelime bilgisinde daha çok gelişme yaşayan çocukların zihin kuramında daha hızlı bir gelişim göstermesi; Wellman'ın bireysel farkları, diğer bilişsel değişkenler üzerinden açıklamasını örnekler niteliktedir. İfade edici kelime bilgisinde yaşadıkları gelişim sayesinde çocuklar, zihin kuramı görevlerinde zihin anlayışlarını daha iyi ifade etmiş ve böylece zihin kuramı açısından daha hızlı bir gelişme göstermiş olabilir. Aynı mantık üzerinden alıcı kelime bilgisinde diğer çocuklara göre daha az gelişme gösteren çocuklar, zihin kuramı görevlerini anlamakta zorlanmış ve böylece dilden dolayı zihin kuramı performanslarında bir düşüş yaşamış olabilirler. Ayrıca Wellman ve Liu'nun geliştirdiği görevde örneğin gerçek-görünen duygu alt görevinin, zihin kuramı çalışmalarında yanlış kanının ölçülmesinde kullanılan klasik yanlış kanı atfı görevlerine göre daha çok alıcı dil kelime bilgisine dayandığ1 düşünülmektedir. Bunun nedeni gerçek görünen duygu görevinde klasik yanlış kanı görevlerine göre daha uzun ve karışık bir hikâye anlatılmasıdır. Böylece bu araştırmada dilden kaynaklı bireysel farklar, çocukların zihin kuramında nasıl bir gelişim göstereceklerini ve bu gelişimin hızını belirlemede önemli bir rol üstlenmiş olabilir.

İkinci olarak Wellman (2012) gelişimsel çeşitlilik ve bireysel farkları çocuğun mevcut zihin kavramı üzerinden açıklamaktadır. O’na göre zihin kuramı görevlerini geçemeyen tüm çocukların zihin ile ilgili aynı kavramsal zemine sahip olduğunu söyleyemeyiz. Bu çocukların zihinsel yapıyı temsil etme güçleri farklıdır ve bu farklı zemin üzerinden gerçekleşen özümleme ve uyumsama ile gelişim hızları da farklılık göstermektedir. Bu araştırmada çocuğun araştırmaya başladığı zamanki mevcut zihin kuramı puanının, 6 ayda zihin kuramında meydana gelen gelişim puanını yordaması; Wellman'ın gelişimsel çeşitliliğin kavramsal zemin aracılığıyla açıllanabileceği görüşünü destekler niteliktedir. Böylece çocukların zihinle ilgili mevcut kavramsal zeminlerinin, ileride ne derece bir gelişim göstereceklerini belirlediği görülmüştür.

Benzer bir bulgu, Peterson ve Wellman’ın (2019) farklı zihinsel durumların anlaşılmasını ölçtüğü ve çocuğun ilk oturumu sırasındaki zihin kuramı puanı üzerinden zihin kuramındaki bireysel farkları incelediği boylamsal çalışmasından gelmektedir. Peterson ve Wellman (2019) yaptıkları hiyerarşik regresyon analizi sonucunda 2. zaman zihin kuramının, 2. Zaman-1. zaman zihin kuramı puan farkından, yaştan, 1. zaman dil puanından bağımsız olarak 1. zaman zihin kuramı puanı ile yordandığını bulmuşlardır. Bu araştırmanın bulguları Peterson ve Wellmanın (2019) araştırmasıyla kısmen benzerlik göstererek 1. zaman zihin kuramının, 2. zaman zihin kuramını yordadığını bulmuştur. Bununla beraber bu araştırmada ifade edici kelime bilgisinde meydana gelen gelişimin de 2. zaman zihin kuramını yordadığı bulunmuştur. Bu uyuşmazlık Peterson ve Wellman'ın (2019) 
çalışması ile bu çalışmanın dilin farklı yönlerini değerlendiriyor olmasından kaynaklanabilir. Mevcut çalışmada dilin alıcı ve ifade edici kelime bilgisi yönü incelenirken, Peterson ve Wellmanın çalışmasında alıcı dil ve sentaks üzerinden inceleme gerçekleştirilmiştir. Dilin farklı yönlerinin ölçülmesi, bulgularda da farklıllğa neden olmuş olabilir. Ayrıca Peterson ve Wellman'ın çalışması 311 yaş arası çocuklar üzerinde yürütülürken bu çalışmada 3-5 yaş çocuklarına odaklanıldığından tam bir karşılaştırma yapmak mümkün değildir. $\mathrm{Bu}$ nedenle alanyazında çocuğun araştırma başlangıcındaki zihin kuramı becerisinin ilerideki zihin kuramı performansını nasıl etkilediğini araştıran daha fazla çalışmaya ihtiyaç vardır.

Mevcut araştırmada ebeveynlerin lise ve üstü eğitim almaları, çocukların genel gelişim düzeyinin normal yaş sınırı arasında olması, çocukların kronik bir rahatsızlığı olmaması gibi etmenler açısından katılımcılar sınırlandırılmıştır. Fakat gelişimsel çeşitlilik ve bireysel farklar açısından anlamlı bulunan kardeş sayısı, sosyo-ekonomik statü gibi çevresel etkenler araştırmaya dâhil edilmemiştir. İlerideki araştırmalarda çevresel etkenlerin de analize dâhil edilmesi bireysel farklar ve gelişimsel çeşitlilik açısından daha kapsamlı bir tablo sunabilir.

Wellman ve Liu'nun geliştirdiği zihin kuramı ölçeği ile var-yok olarak ele alınan zihin kuramı anlayışının, daha gelişimsel bir süreç olarak ele alınmasının ve farklı zihinsel durumların değerlendirilmesinin mümkün olacağı düşünülmektedir. Fakat bu ölçek geçti-kaldı (0-1) olarak puanlandığından çocuklar arasındaki kavramsal zemin farkı tam olarak derecelendirilememiş olabilir. İleriki çalışmalar zihin kuramı ölçeği kullanmanın yanında çocukların cevaplarını gerekçelendirmelerini de içererek bireysel farkların daha hassas ölçülmesini sağlayabilir. Bu çalışmada zihin kuramının arzu, bilgi, kanı, yanlış kanı, bilgi ve duygu gibi farklı zihinsel durumlar üzerinden değerlendirilmesi ve 6 aylık bir zaman dilimini kapsaması gibi yöntemsel özellikleri nedeniyle zihin kuramı gelişimsel olarak ele alınmıştır. Zihin kuramı alanyazınında fazla çalışılmayan gelişimsel çeşitlilik ve bireysel farkları ele aldığı için ve gelişimsel bir bakış açısıyla oluşturulduğu için bu çalışmanın literatüre önemli katkı sağladığı düşünülmektedir.

\section{KAYNAKÇA}

Amsterlaw, J. ve Wellman, H.M. (2006) Theories of mind in transition: A microgenetic study of the development of false-belief understanding. Journal of Cognition and Development, 7(2), 139_ 172.

Astington, J. W. ve Jenkins J. (1999). A longitudinal study of the relation between language and theory of mind development. Developmental Psychology, 35, 1311-1320.

Berument, S. K. ve Güven, A. G. (2010). Türkşe Ifade Edici ve Alıc Dil Testi: Ahcı Dil Alt Testi (TIFALDI-RT). Ankara: Türk Psikologlar Derneği. 
Carlson, S. M., Moses, L. J. ve Breton, C. (2002). How Specific is the relation between executive function and theory of mind? Contributions of inhibitory control and working memory. Infant and Child Development, 11, 73-92.

Cutting A.L. ve Dunn J. (1999). Theory of mind, emotion understanding, language, and family background: Individual differences and interrelations. Child Development, 70, 853-865.

de Ribaupierre, A. ve Bailleux, C. (1994). Developmental change in a spatial task of attentional capacity: An essay toward an integration of two working memory models. International Journal of Behavioral Development, 17, 5-35.

de Villiers J.G. ve de Villiers, P. A. (2000). Linguistic determinism and the understanding of false beliefs. İçinde P. Mitchell ve K. J. Riggs (Ed.) Children's Reasoning and The Mind (s. 191-228), Hove, England: Psychology Press, Taylor \& Francis (UK).

Flavell, J.H. (1988). The development of children's knowledge about the mind: From cognitive connections to mental representations. İçinde J.W. Astington, P.L. Harris, ve D.R. Olson (Ed.), Developing Theories of Mind (s. 244-267), New York: Cambridge University Press.

Flavell, J.H. (1999). Cognitive development: Children's knowledge about the mind. Annu. Rev. Psychol., 50, 21-45.

Flavell, J.H., Miller, P.H. ve Miller, S.A. (2002). Cognitive Development (4. Basim), Upper Saddle River, NJ: Prentice Hall.

Frye, D., Zelazo, P.D. ve Palfai, T. (1995). Theory of mind and rule-based reasoning. Cognitive Development, 10, 483-527.

Garon, N., Bryson, S. E., \& Smith, I. M. (2008). Executive function in preschoolers: A review

using an integrative framework. Psychological Bulletin, 134, 31-60.

Gordon, A.C.L. ve Olson, D.R. (1998). Mind and the capacity to hold in mind. Journal of Experimental Child Psychology, 68, 70-83.

Hasselhorn, M., Mahler, C. ve Grube, D. (2005). Theory of mind, working memory, and verbal ability in preschool children: The proposal of a relay race model of the developmental dependencies. İçinde Schneider, W., Schumann-Hengsteler, R., Sodian B. (Ed) Young Children's Cognitive Development: Interrelationships among executive functioning, working memory, verbal ability, and theory of mind (s. 220-237). Lawrence Erlbaum Associates.

Hughes, C. (1998). Executive function in preschoolers: Links with theory of mind and verbal ability. British Journal of Developmental Psychology, 16, 233-253.

Hughes, C., Jaffe, S. R., Happe', F., Taylor, A., Caspi, A. ve Moffitt, T. E. (2005). Origins of individual differences in theory of mind: From nature to nurture? Child Development, 76, 356370.

Ilgaz, H. ve Allen J. W. P. (2020). (Co-)Constructing a theory of mind: From language or through language? Synthese, 1-22. 
Kahraman, Ö. G. (2012). Zibin kuramma dayah eğitim programmın 48-60 aylhk çocuklarmn bilissel bakęs açısı becerileri ve prososyal davranıslar üzerindeki etkisinin incelenmesi (Basılmamış Doktora Tezi), Gazi Üniversitesi, Ankara.

Karakelle, S. ve Ertuğrul Z. (2012). Zihin kuramı ile çalışma belleği, dil becerisi ve yönetici işlevler arasındaki bağlantılar küçük (36-48 ay) ve büyük (53-72 ay) çocuklarda farklılık gösterebilir mi? Türk Psikoloji Dergisi, 27(70), 1-25.

Mischel, W., Shoda, Y. ve Rodriguez, M. L. (1989). Delay of gratification in children. Science, 244, 933-938.

Moses, L.J. ve Tahiroglu, D. (2010). Clarifying the relation between executive function and children's theories of mind. İçinde Sokol, B., Muller, U., Carpendale, J., Young, A., Iarocci, G. (Ed.) Self and social regulation: Social interaction and the development of social understanding and executive functions (s.218-233). New York, NY: Oxford; 2010.

Oberauer, K. (2005). Executive functions, working memory, verbal ability, and theory of mindDoes it all come together? İçinde Schneider, W., Schumann-Hengsteler, R., Sodian B. (Ed.) Young children's cognitive development: Interrelationships among executive functioning, working memory, verbal ability, and theory of mind (s. 285-299). Lawrence Erlbaum Associates.

Perner, J. (1991). Understanding the representational mind. Imprint Cambridge, Mass.:MIT Press.

Peterson, C.C. ve Wellman, H.M. (2019). Longitudinal theory of mind (ToM) development from preschool to adolescence with and without ToM delay. Child Development, 90, 1917-1934.

Premack, D. ve Woodruft, G. (1978). Does the chimpanzee have a theory of mind. Behavioral and Brain Sciences, 1, 515-526.

Repacholi, B., ve Slaughter, V. (2003). Macquarie monographs in cognitive science. Individual differences in theory of mind: Implications for typical and atypical development. New York: Psychology Press.

Ruffman, T., Naito, M., $\quad$ Perner, J., Parkin, L. ve Clements, W. A. (1998). Older (but not younger) siblings facilitate false belief understanding. Developmental Psychology, 34, 161-174.

Ruffman, T., Slade, L. ve Crowe, E. (2002). The relation between children's and mothers' mental state language and theory-of-mind understanding. Child Development, 73(3), 734-751.

Savaşır, I., Sezgin, N. ve Erol, N. (1993). Ankara Gelişim Tarama Envanteri (2. basım). Ankara: Türk Psikologlar Derneği.

Schneider, W., Lockl, K., Fernandez, O. (2005). Interrelationships among theory of mind, executive control, language development, and working memory in young children: A longitudional analysis. İçinde Schneider, W., Schumann-Hengsteler, R. ve Sodian B (Ed.) Young children's cognitive development: Interrelationships among executive functioning, working memory, verbal ability, and theory of mind (s. 239-258). Lawrence Erlbaum Associates.

Selcuk, B., Brink, K. A., Ekerim, M., ve Wellman, H. M. (2018). Sequence of theory-of-mind acquisition in Turkish children from diverse social backgrounds. Infant and Child Development, 27(4), 2098. 
Selçuk, B. ve Yavuz, H. M. (2018). Erken çocukluk gelişimine dair Türkiye bulgularına bakış. Erken Cocukluk Çalşsmalar Dergisi, 2 (2), 334-363.

Shahaeian, A., Peterson, C. C., Slaughter, V., ve Wellman, H. M. (2011). Culture and the sequence of steps in theory of mind development. Developmental Psychology, 47(5), 1239-1247.

Slade, L ve Ruffman, T., (2005). How Language does relate to theory of mind: A longitudional study of syntax, semantics, working memory and false belief. British Journal of Developmental Psychology, 23,117-141.

Slade, L., Sodian, B., Taylor, C. ve Keenan, T., (1998). Memory span as a predictor of false belief understanding. New Zealand Journal of Psychology, 27, 36-46.

Sodian, B. (2005). Theory of mind--The case for conceptual development. İçinde W. Schneider, R. Schumann-Hengsteler, ve B. Sodian (Ed.) Young children's cognitive development: Interrelationships among executive functioning, working memory, verbal ability, and theory of mind (s. 95-103). Lawrence Erlbaum Associates Publishers.

Tabachnick, B.G. ve Fidell, L.S. (2013). Using Multivariate Statistics (6. basim). Boston: Pearson.

Tomasello, M. (2018). How children come to understand false beliefs: A shared intentionality account. Proceedings of the National Academy of Sciences, 115 (34), 8491-8498.

Wellman, H.M. (2012). Theory of mind: Better methods, clearer findings, more development. European Journal of Developmental Psychology, 9 (3), 313-330.

Wellman, H.M., Cross, D. ve Watson, J. (2001). Meta-Analysis of theory-of-mind development: The truth about false belief. Child Development, 72(3):655-84.

Wellman, H.M., Fang, F. ve Peterson, C.C. (2011). Sequential progressions in a theory of mind scale: Longitudinal perspectives. Child Development, 82, 780-792.

Wellman, H.M. ve Liu, D. (2004). Scaling of theory-of-mind tasks. Child Development, 75(2), 523541.

Wellman, H.M., Fang, F., Liu, D., Zhu, L., Liu, G. (2006). Scaling of ToM understandings in Chinese children. Psychological Science, 17(12), 1075-1081.

Yağmurlu, B., Berument, S. K. ve Celimli, S. (2005). The role of institution and home contexts in theory of mind development. Applied Developmental Psychology, 26 (2005) 521-537. 